\title{
Seasonal Incidence and Influence of Environmental Factors on the Aphid Complex on Cabbage (Brassica oleracea var. capitata L.) Crop
}

\author{
P. Bhagat ${ }^{*}$, Y.K. Yadu and V.K. Dubey \\ Department of Entomology, College of Agriculture, Indira Gandhi Krishi Vishwavidyalaya, \\ Raipur, Chhattisgarh, India \\ *Corresponding author
}

\section{A B S T R A C T}

\begin{tabular}{|l|}
\hline Key w or d s \\
Population dynamics, \\
Aphid, Cabbage, \\
Correlation, Weather \\
parameters
\end{tabular}

Studies on seasonal incidence of aphid (Brevicoryne brassicae L.), infesting cabbage (Brassica oleracea var. capitata L.) work was carried out at College of Agriculture, Indira Gandhi Krishi Vishwavidyalaya, Raipur (C.G.) during 2015-16 and 2016-17. The Brevicoryne brassicae L. damage was observed with a varying degree of infestation. The peak population of aphid, Brevicoryne brassicae L., was observed 172.5 / 20 plants and 140.45/ 20 plants in month of Febuary during both years (2015-16 and 2016-17), respectively. Thereafter population started declining. Correlation studies revealed that maximum $(\mathrm{r}=-0.19, \mathrm{r}=0.31)$, minimum $(\mathrm{r}=-0.15, \mathrm{r}=-0.33)$ and average $(\mathrm{r}=-0.18, \mathrm{r}=-$ 0.32 ) temperature had non significantly negative association with aphids infesting cabbage during both years (2015-16 and 2016-17), respectively. The association between aphids of cabbage and relative humidity $(\mathrm{r}=0.34, \mathrm{r}=0.39)$ as well as sunshine hours $(\mathrm{r}=-0.13, \mathrm{r}=$ 0.26) was not established during years, 2015-16 and 2016-17 respectively. There was no definite relationship between aphid population in cabbage and rainfall in both years with their correlation values $(\mathrm{r}=-0.13$ and $\mathrm{r}=0.26)$, respectively.

\section{Introduction}

India is the world's second largest producer of vegetables next to China. The total production of vegetable in India is 16.66 million tons and the total area is about 95.75 million ha (Anonymous, 2015-16). Cabbage (Brassica oleracea var. capitata L.) is a popular leafy green vegetable. Cabbage is a good yielding and remunerative rabi vegetable crop. The crop is attacked and devastated by an array of insect- pests. This crop is attacked by 375 species of insects (Oatman and Plantner, 1969). One of the major constraints of not attaining higher yield of crucifers is the damage caused by insect pests. The major insect pests, which cause maximum yield losses in cabbage are Diamond back moth (DBM), Plutella xylostella L.; Cabbage butterfly, Pieris brassicae L.; leaf webber, Crocidolomia binotalis; cabbage borer, Hellula undalis Fab., mustard aphid, Lipaphis erysimi (Kalt.) and cabbage aphid, Brevicoryne brassicae L., In India, the area under cabbage cultivation is around 3.69 lakh hectare with 79.49 lakh tones production and average yield of 21.5MT/ha during 2010-11 (Anonymous 2011). The cabbage aphid has 
been observed as the most destructive and wide spread throughout the world (Sharma and Bhalla, 1964). The estimated loss in yield due to aphid, L. erysimi in cabbage crop was 47.1 to 96.0 per cent (Bakhetia, 1986 and Suri et al., 1988).

The aphids, due to their sucking propensities devitalise the plant tissues leading to yield reduction and their presence reduce the quality of cabbage heads. The physiological development of the host plant has been shown to influence the pattern of aphid infestations within a plant (Ibbotson and Kennedy 1950). Kennedy (1958) stated that the apex leaves, as sites of protein synthesis, and the oldest leaves which were going leaf proteolysis, were frequently preferred sites for aphid attack because of high soluble nitrogen levels. This hypothesis has been supported by observations on the distribution of the green peach aphid (GPA), Myzus persicae (Sulzer), and the cabbage aphid, Brevicoryne brassicae (L.), on a variety of host plants.

\section{Materials and Methods}

Cabbage cv. Golden Acre was sown in $100 \mathrm{~m}^{2}$ area by adopting $60 \times 45 \mathrm{~cm}$ spacing, divided into two plots each measuring $10 \times 10 \mathrm{~m}$, at the experimental area of Indira Gandhi Agricultural University, Raipur (C.G.) during rabi seasons, 2015-2016 and 2016-2017. No insecticidal treatment was applied at any stage of the crop growth. Observation of aphid was recorded from two leaves /plant covering three regions /leaf on randomly selected twenty plants from each plot at weekly interval using one square inch template made of card board. Observations on population of aphids on twenty randomly selected cabbage plants in each experimental field from pest appearance until harvest of crops at weekly interval. It was then, correlated with weather parameters viz., maximum temperature, minimum temperature, relative humidity, rainfall and sunshine hours. The data on the pest incidence were statistically analysed for the seasonal incidence and then computed with correlation co-efficient studies to see the effect of different abiotic factors on the population of aphids.

\section{Results and Discussion}

Aphids first appeared in $52^{\text {th }}$ SMW. (Standard Meteorological Week) during both years (2015-2016 and 2016-2017). The population of aphids reached at its peak of 172.5 / 20 plants in $6^{\text {th }}$ standard week during 2015-16, while it was $140.45 / 20$ plants in $6^{\text {th }}$ S.M.W. during 2016-17 (Table 1 and 2).

Severity of aphid incidence was higher on first year as compared to second year. Atwal and Sethi (1963) noted the peak population of aphids in the month of January and then the population decreased. Similarly, Roy (1975) observed that the population of this pest gradually rise until it reached the peak in January month after which it declined. Patel (2002) has also reported that the maximum activity period of aphid was during December to January at Raipur (C.G.). These reports are in accordance with present findings.

The correlation coefficient analysis (Table 3 and 4$)$ revealed that maximum $(\mathrm{r}=-0.19, \mathrm{r}=$ $0.31)$, minimum $(r=-0.15, r=-0.33)$ and average $(\mathrm{r}=-0.18, \mathrm{r}=-0.32)$ temperature had non significantly negative association with aphids infesting cabbage during both years (2015-16 and 2016-17), respectively. The association between aphids of cabbage and relative humidity $(r=0.34, r=0.39)$ as well as sunshine hours $(r=-0.13, r=0.26)$ was not established during both years, 2015-16 and 2016-17 respectively. There was no definite relationship between aphids population in cabbage and rainfall during 2015-16 and 2016-17 with their correlation values $(r=-0.13$ and $r=0.26$, respectively). 
Table.1 Weather parameters and aphid population during rabi season, 2015-2016

\begin{tabular}{|c|c|c|c|c|c|c|c|c|c|c|}
\hline \multirow[t]{2}{*}{ SMW } & \multirow{2}{*}{$\begin{array}{c}\text { Date of } \\
\text { observation }\end{array}$} & \multicolumn{3}{|c|}{ Temperature $\left({ }^{\circ} \mathrm{C}\right)$} & \multicolumn{3}{|c|}{ Relative humidity (\%) } & \multirow{2}{*}{$\begin{array}{l}\text { Sun shine } \\
\text { (Hours) }\end{array}$} & \multirow{2}{*}{$\begin{array}{c}\text { Rainfall } \\
\text { (mm) }\end{array}$} & \multirow{2}{*}{$\begin{array}{c}\text { Aphids / } 20 \\
\text { plants }\end{array}$} \\
\hline & & Maximum & Minimum & Average & Morning & Evening & Average & & & \\
\hline $52^{\text {th }}$ & $29 / 12 / 2015$ & 25.79 & 12.00 & 18.895 & 87.86 & 39.83 & 63.845 & 4.61 & 0.14 & 0.55 \\
\hline $1^{\text {st }}$ & 05/01/2016 & 30.77 & 11.99 & 21.38 & 81.57 & 27.29 & 54.43 & 8.09 & 0.00 & 4.35 \\
\hline $2^{\text {nd }}$ & $12 / 01 / 2016$ & 29.63 & 11.37 & 20.5 & 87.29 & 25.00 & 56.145 & 6.80 & 0.00 & 12.475 \\
\hline $3^{\text {rd }}$ & $19 / 01 / 2016$ & 28.40 & 14.20 & 21.3 & 86.29 & 43.86 & 65.075 & 5.41 & 0.00 & 59.35 \\
\hline $4^{\text {th }}$ & $26 / 01 / / 2016$ & 26.07 & 8.64 & 17.355 & 91.14 & 34.00 & 62.57 & 7.47 & 0.29 & 80.525 \\
\hline $5^{\text {th }}$ & $02 / 02 / 2016$ & 30.89 & 14.03 & 22.46 & 87.14 & 35.14 & 61.14 & 8.37 & 0.00 & 129.2 \\
\hline $6^{\text {th }}$ & 09/02/2016 & 31.30 & 14.28 & 22.79 & 77.00 & 26.61 & 51.805 & 8.79 & 0.00 & 172.5 \\
\hline $7^{\text {th }}$ & $16 / 02 / 2016$ & 31.81 & 19.30 & 25.555 & 80.43 & 41.43 & 60.93 & 5.15 & 0.07 & 141.725 \\
\hline $8^{\text {th }}$ & $23 / 02 / 2016$ & 34.77 & 18.99 & 26.88 & 72.71 & 28.86 & 50.785 & 7.80 & 0.00 & 112.7 \\
\hline $9^{\text {th }}$ & $02 / 03 / 2016$ & 33.13 & 20.90 & 27.015 & 79.29 & 41.14 & 60.215 & 2.63 & 0.00 & 78.925 \\
\hline $10^{\text {th }}$ & 09/03/2016 & 30.73 & 20.57 & 25.65 & 76.00 & 27.00 & 51.5 & 7.25 & 0.09 & 29.125 \\
\hline $11^{\text {th }}$ & $16 / 03 / 2016$ & 33.84 & 20.57 & 27.205 & 62.63 & 29.86 & 46.245 & 6.76 & 0.41 & 25.675 \\
\hline $12^{\text {th }}$ & 23/03/2016 & 40.12 & 23.22 & 31.67 & 59.35 & 26.77 & 43.06 & 7.44 & 0.00 & 20.275 \\
\hline $13^{\text {th }}$ & $30 / 03 / 2016$ & 40.44 & 23.47 & 31.955 & 60.00 & 22.57 & 41.285 & 9.22 & 0.00 & 20.475 \\
\hline $14^{\text {th }}$ & 06/04/2016 & 41.10 & 24.34 & 32.72 & 60.05 & 17.90 & 38.975 & 8.47 & 0.00 & 7.525 \\
\hline & al Mean & 32.59 & 17.19 & 24.89 & 76.58 & 31.15 & 53.86 & 6.95 & 0.07 & 59.69 \\
\hline
\end{tabular}

SMW= Standard Meteorological Week 
Table.2 Weather parameters and aphid population during rabi season, 2016-2017

\begin{tabular}{|c|c|c|c|c|c|c|c|c|c|c|}
\hline \multirow[t]{2}{*}{ SMW } & \multirow{2}{*}{$\begin{array}{c}\text { Date of } \\
\text { observation }\end{array}$} & \multicolumn{3}{|c|}{ Temperature $\left({ }^{\circ} \mathrm{C}\right)$} & \multicolumn{3}{|c|}{ Relative humidity (\%) } & \multirow{2}{*}{$\begin{array}{l}\text { Sun shine } \\
\text { (Hours) }\end{array}$} & \multirow{2}{*}{$\begin{array}{c}\text { Rainfall } \\
\text { (mm) }\end{array}$} & \multirow{2}{*}{$\begin{array}{l}\text { Aphids / } 20 \\
\text { plants }\end{array}$} \\
\hline & & Maximum & Minimum & Average & Morning & Evening & Average & & & \\
\hline $52^{\text {th }}$ & $25 / 12 / 2016$ & 27.8 & 9.5 & 18.65 & 85.4 & 26.3 & 55.85 & 7.6 & 0 & 2.575 \\
\hline $1^{\text {st }}$ & 01/01/2017 & 29 & 12.07 & 20.535 & 89.71 & 33.86 & 61.785 & 6.39 & 0 & 12.65 \\
\hline $2^{\text {nd }}$ & 08/01/2017 & 28.24 & 12.66 & 20.45 & 86.14 & 33.71 & 59.925 & 6.69 & 0.8 & 69.55 \\
\hline $3^{\text {rd }}$ & $15 / 01 / 2017$ & 27.73 & 10.46 & 19.095 & 83.14 & 26 & 54.57 & 8.23 & 0 & 74.9 \\
\hline $4^{\text {th }}$ & $22 / 01 / 2017$ & 29.84 & 13.21 & 21.525 & 84.29 & 28.29 & 56.29 & 8.66 & 0 & 80.1 \\
\hline $5^{\text {th }}$ & 29/01/2017 & 29.89 & 13.33 & 21.61 & 79 & 27.71 & 53.355 & 8 & 0 & 101 \\
\hline $6^{\text {th }}$ & 05/02/2017 & 31.63 & 12.94 & 22.285 & 83.86 & 24.29 & 54.075 & 9.6 & 0 & 140.45 \\
\hline $7^{\text {th }}$ & $12 / 02 / 2017$ & 31.19 & 16.19 & 23.69 & 79.57 & 34.29 & 56.93 & 6.37 & 0.8 & 123.975 \\
\hline $8^{\text {th }}$ & $19 / 02 / 2017$ & 33.89 & 15.29 & 24.59 & 75 & 18.14 & 46.57 & 10.24 & 0 & 78 \\
\hline $9^{\text {th }}$ & $26 / 02 / 2017$ & 33.54 & 14.53 & 24.035 & 68.29 & 15.29 & 41.79 & 10.06 & 0 & 69.25 \\
\hline $10^{\text {th }}$ & 05/03/2017 & 33.81 & 19 & 26.405 & 67.29 & 30.29 & 48.79 & 7.3 & 0.79 & 47.6 \\
\hline $11^{\text {th }}$ & $12 / 03 / 2017$ & 32.2 & 17.19 & 24.695 & 60.86 & 21.43 & 41.145 & 8.26 & 0 & 27.9 \\
\hline $12^{\text {th }}$ & 19/03/2017 & 35.17 & 18.96 & 27.065 & 65.14 & 18.14 & 41.64 & 9.07 & 0 & 22.6 \\
\hline $13^{\text {th }}$ & 26/03/2017 & 40.4 & 22.61 & 31.505 & 60.86 & 13.57 & 37.215 & 8.93 & 0 & 20.5 \\
\hline $14^{\text {th }}$ & 02/04/2017 & 41.43 & 25.87 & 33.65 & 52.71 & 16.14 & 34.425 & 8.37 & 0 & 15.5 \\
\hline \multicolumn{2}{|c|}{ Seasonal Mean } & 32.38 & 15.59 & 23.99 & 74.75 & 24.50 & 49.62 & 8.25 & 0.16 & 59.10 \\
\hline
\end{tabular}

SMW= Standard Meteorological Week

Table.3 Simple correlation coefficient (r) between meteorological parameters and Aphids population during rabi 2015 -16

\begin{tabular}{|c|c|c|c|c|c|c|}
\hline \multirow{3}{*}{$\begin{array}{l}\text { Weather data } \\
\qquad \text { Aphid population }\end{array}$} & \multicolumn{3}{|c|}{ Temperature $\left({ }^{\circ} \mathrm{C}\right)$} & \multirow{2}{*}{$\begin{array}{l}\text { Relative humidity } \\
\qquad(\%) \text { A verage }\end{array}$} & \multirow{2}{*}{$\begin{array}{l}\text { Sunshine } \\
\text { (hours) }\end{array}$} & \multirow{2}{*}{$\begin{array}{c}\text { Rainfall } \\
\text { (mm) }\end{array}$} \\
\hline & Maximum & Minimum & Average & & & \\
\hline & -0.19 & -0.15 & -0.18 & 0.34 & 0.02 & -0.13 \\
\hline
\end{tabular}

Non-significant correlation

Table.4 Simple correlation coefficient (r) between meteorological parameters and Aphids population during rabi 2016 -17

\begin{tabular}{|c|c|c|c|c|c|c|}
\hline \multirow{3}{*}{$\begin{array}{l}\text { Weather data } \\
\text { Aphid population }\end{array}$} & \multicolumn{3}{|c|}{ Temperature $\left({ }^{\circ} \mathrm{C}\right)$} & \multirow{2}{*}{$\begin{array}{l}\text { Relative humidity } \\
(\%) \text { Average }\end{array}$} & \multirow{2}{*}{$\begin{array}{l}\text { Sunshine } \\
\text { (hours) }\end{array}$} & \multirow{2}{*}{$\begin{array}{l}\text { Rainfall } \\
\text { (mm) }\end{array}$} \\
\hline & Maximum & Minimum & Average & & & \\
\hline & -0.31 & -0.33 & -0.32 & 0.39 & 0.13 & 0.26 \\
\hline
\end{tabular}


Results of correlation coefficients (r) are agreed with many workers who recorded negative influence of rainfall on aphid population (Ashfaq et al., 2007; Nasir \& Ahmad 2001). Sachan and Srivastava (1972) showed that relative humidity of 60.7 to 72.3 per cent favours the multiplication of aphids on cabbage. Findings are slightly contradict with the reports of Bhat et al., (2012) who recorded positive nonsignificant correlation with both maximum and minimum temperature on population build-up of aphids in four varieties of cabbage during 1998-99 at Kashmir Valley whereas Patra et al., (2012) reported negative influence of temperature, and rainfall on population build-up of aphid at Meghalaya condition. Results may be corroborated with the findings of Zaz (2001) who reported that the aphid population exhibited non-significant negative correlations with overall temperature in cabbage.

\section{References}

Anonymous. 2011. Indian Horticulture Database, National Horticulture Board, Ministry of Agriculture, Government of India, 85, Institutional Area, Sector-18, Gurgaon-122015, India, 141.

Anonymous. 2015-16. Indian horticulture production, Press Information Bureau Government of India Ministry of Agriculture \& Farmers Welfare.

Ashfaq, M., Iqbal, J., Ali, A. and Farooq, U. 2007. Role of abiotic factors in population fluctuation of aphids on wheat. Pakistan Entomology, 29:11722.

Atwal, A.S. and Sethi, S.L., 1963. Predation by Coccinella septumpunctata Linn. on the cabbage aphid, Lipaphis erysimi (Kalt.) in India. J. Anim. Ecol., 32: 481-88.
Bakhetia, D.R.C., 1986. Pest management in cruciferous crops. Pesticides, 20 (5): 32-38.

Bhat, A.M., Hussain, B. and Dar, H.M., 2012. Population dynamics and infestation index of cabbage aphid, Brevicoryne brassicae [Homoptera: Aphididae] in Kashmir Valley. Trends in Biosciences, 5: 284-86.

Ibbotson, A. and Kennedy, J.S., 1950. The distribution of aphid infestation in relation to leaf age. II. The progress of Aphis fabae infestations on sugar beets in pots. Ann. Appl. Biol. 37: 680-696.

Kennedy, J.S., 1958. Physiological condition of the host- plant and susceptibility to aphid attack. Entomol. Exp. Appl.1 50-65.

Nasir, S., Ahmad, F., 2001. Correlation between wheat aphid population and abiotic factors. Pakistan Entomology, 23: 23-25.

Oatman, E.R. and Plantner, G.R., 1969. An ecological study of insect populations on cabbage in southern California. Hilgardia, 40 (1): 1-40.

Patel, P. R., 2002. Studies on diamond back moth Plutella xylostella L. with special reference to its management through new chemical insecticide on cabbage crop. M.Sc. (Ag). Thesis. Dept. of Entomology. I.G.K.V. Raipur (C.G.).

Patra S., Thakur, N.S.A., Saikia, K. and Firake, D.M., 2012. Population dynamics of cabbage aphid, Brevicoryne brassicae $\mathrm{L}$. on major cole crops in Meghalaya. Madras Agricultural Journal, 99:573-75.

Roy, P., 1975. Population dynamics of mustard aphid, Lipaphis erysimi (Kalt.) in West Bengal. Indian J. Ent., 37 (3): 318-21.

Sachan, J.N. and Srivastava, B.P., 1972. Studies on the seasonal incidence of 
insect-pests of cabbage. Indian J. Ent., 34 (2): 123-29.

Sharma, P.L. and Bhalla, O.P., 1964. A survey study of insect pests of economic importance in Himachal Pradesh. Indian J. Ent., 26: 318-31.

Suri, S.M., Singh, O.P. and Rawat, R.R., 1988. Development of pest management programme in Brassica. Pesticides, 7 (1): 30-38.

Zaz, G.M., 2001. Incidence and population build-up of cabbage aphid, Brevicoryne brassicae L. on cabbage and cauliflower. Applied Biological Research, 3: 51-53.

\section{How to cite this article:}

Bhagat, P., Y.K. Yadu and Dubey, V.K. 2018. Seasonal Incidence and Influence of Environmental Factors on the Aphid Complex on Cabbage (Brassica oleracea var. capitata L.) Crop. Int.J.Curr.Microbiol.App.Sci. 7(03): 995-1000.

doi: https://doi.org/10.20546/ijcmas.2018.703.118 